\title{
- Water-Rock
}

$\rightarrow$ Interaction
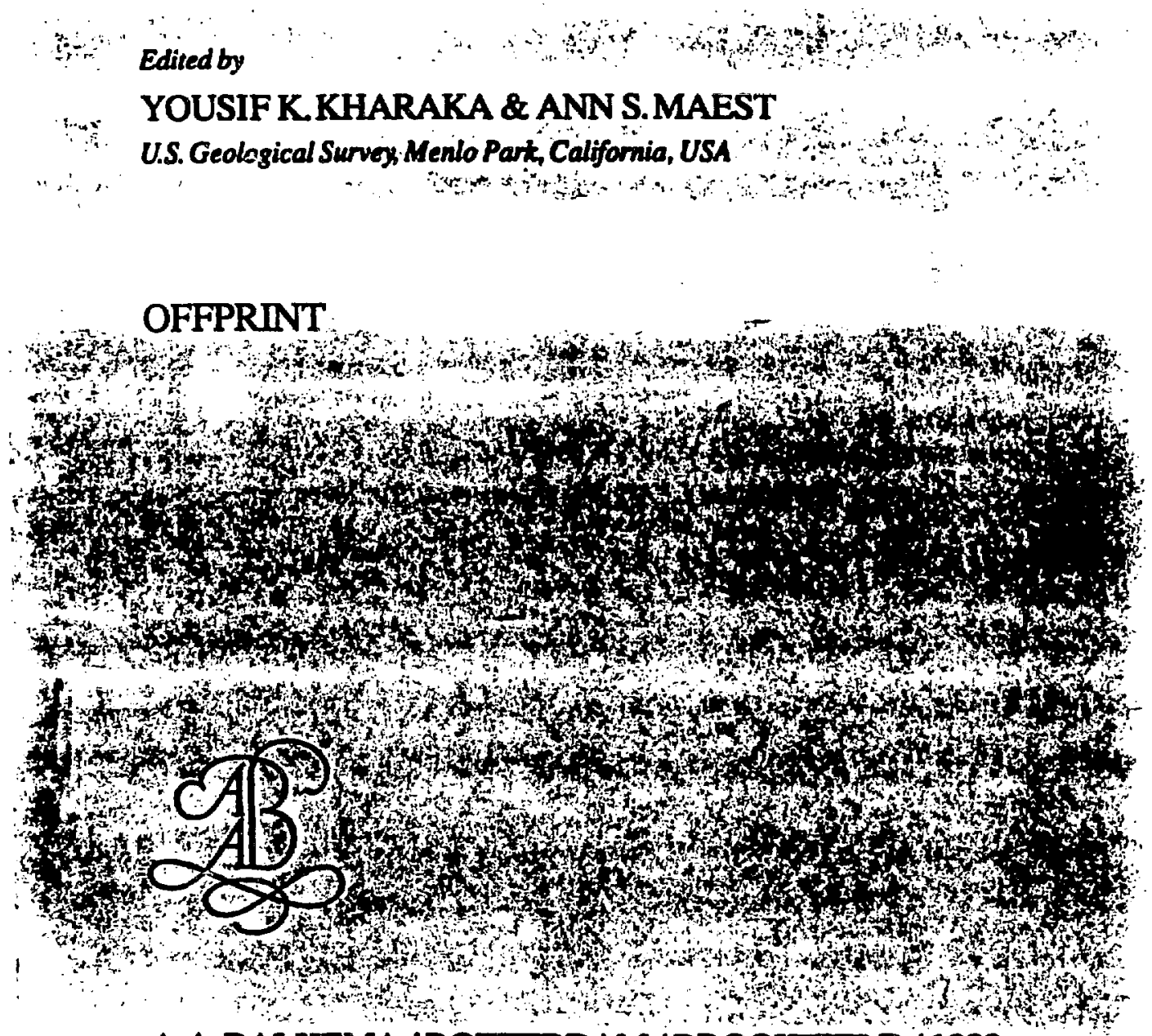

\section{A.A.BALKEMA/ROTTERDAM/BROOKFIELD/ 1992}

\section{DISCLAIMER}

This report was prepared as an account of work sponsored by an agency of the United States Government. Neither the United States Government nor any agency thereof, nor any of their employees, makes any warranty, express or implied, or assumes any legal liability or responsibility for the accuracy, completeness, or usefulness of any information, apparatus, product, or process disclosed, or represents that its use would not infringe privately owned rights. Reference herein to any specific commercial product, process, or service by trade name, trademark, manufacturer, or otherwise does not necessarily constitute or imply its endorsement, recom. mendation, or favoring by the United States Government or any agency thereof. The views and opinions of authors expressed lerein do not necessarily state or reflect those of the United States Government or any agency thereof. 


\title{
A preliminary study of the chemistry of pore water extracted from tuff by one-dimensional compression
}

\author{
C.A.Peters \& I.C.Yang \\ US Gevlogical Suriey. Denver. Colo.. USA \\ J.D. Higgins \\ Colorado School of Mines. Gulden. Culo.. USA \\ P.A. Burger \\ US Bureau of Reclamation. Denver. Colo.. USA
}

\begin{abstract}
A specially denigned and fabricatud one-dimeneionel compreeston cell is belng uaed to oxtract water from nonwelded and denely welded tuffe having degrees of aeturation greater than 16 and 37 percent reppeceively. Chemical anelyese of pore water obteined at increasing prebeuren aro used to eveluate poasible changes in chomiotry caued by comprebion. The extracted pore water varies from a calciun chloride type to a adiu. bicarbonate typ. The mean coneentration of dileolved lone gonerelly decrenees during coapresion. The relative abundance of the rejor catione varies little with increating prebeure. The roletive abundence of the major anione varioe moderietoly with increasing proveure. Poesible caune of the poreweter-chenietry changes includes 1 ) dilution of pore weter by low lonic etrength aduorbed water from zeolites and claya, 2) diasolution reactione ceuned by the increse in diseolved earbon dioxide concentratione that why realt frou preseurization, 3) mambane flitration by zeolites and clayes and 4 ) ion exchange with the zeolltes and claye.
\end{abstract}

\section{INTRODUCTION}

The U.S. Dopartmont of Enorgy is atudying Yucca Mountain. Nevada, an a potential gite for a high-level radioactive wate repository. An evaluation of the hydrologic syerem in the unsaturated tuff at Yucca Mountain by the U.S. Geological Survey (USGS), includes a hydrochemical gludy to aseese characterigtics of the system, such as traveltime, flowpaths. recharge and source relations, and reaction chemistry of the unsaturated tuff. The objectives of this research are: (1) to develop a viable technicue for extracting pore water from cores of unaturated, nonwelded and deneely welded tuffs by compresaion, and (2) to investigate the effects of tine extraction mothod on the original pore-water composition. This paper describee and presente preliminary results of an evaluation of the changes in pore-water chemietry due to one-timoneional compresaion of pore water by extraction.

Cores used in the study were collected from drill holea UE-25 Uz $\$ 4$, UE-25 Uz $\neq 5$, and USW UZ-13 located on Yuece Mountain and from the U12g tunnel complex (G-tunnel) at Rólnier Mesa, Nevada (Figure 1). These sample sites are located on or near the Nevada Test site (NTS), which is about 110 kilometers northwost of Las Vegas, Nevada. Several additional cerea were obtained from a aite (Apache Laap) near Suparior. Arizona.

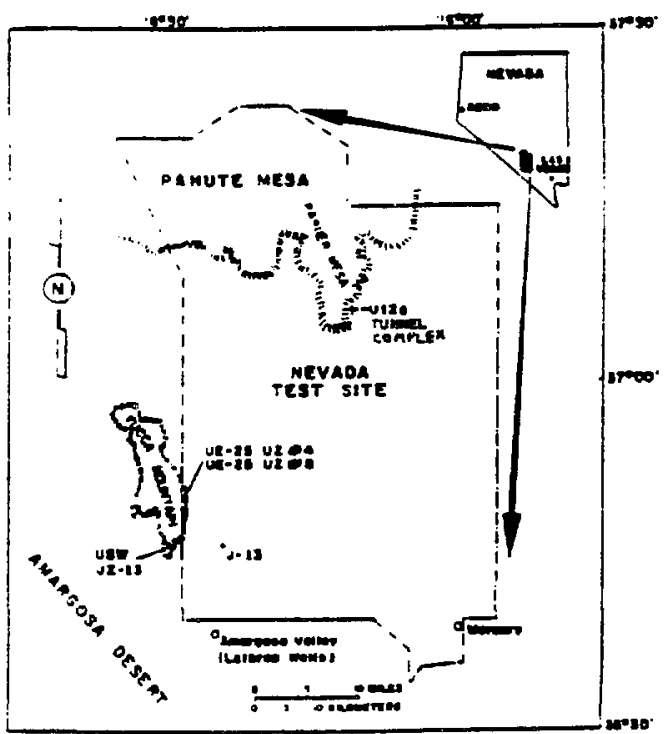

Figure 1. Location of sample sites on and near the Mevede lest site, and nestby geographic featuras in scuthern Mevada.

Pore water and gaseg were extracted from welded and nonwelded tuff samplea at various prestures up to 830 megapascala durıng compreasion. Pore water was analyzed for major ions, specific conductance, and pH. Gas amples were analyzed for carbon dioxide, mothane, and sulfur hexafluoride. 
2 PORE-WATER AND PORE-GAS EXTRACTION METHODS

The one-dimenezonel compraevion ayotem ueed in this etudy, deeigned and built by the USGS and the U.S. Bureau of Reclamation (Mower and othera, 1990; Eigure 2), is made of heet-tranted 4340-alloy stael and agehardened Monel $K 500$ nickel alloy. The rock sample is wrapped in a tefion oheet and confined in the ample sleeve. The drainage plates heve holee for porg-water and pore-gae extraction that are connected by nyion tubing to syringe for water and gas collection. The cell hae a maximum compreselve atrese rating of 552 megapescals and cen sccomodete cores up to $110 \mathrm{~m} 111 \mathrm{i}-$ metere in length and 61 mo in diamater. $A$ gecond-generation cell ande principdly of c250 taraging ateel that has a maximum compreneive strese reting of 830 angepacels war eleo unad for compreseion in thil etudy. The design of thie cell ie similar to the original one-dimensional cell (Flgure 2 ).

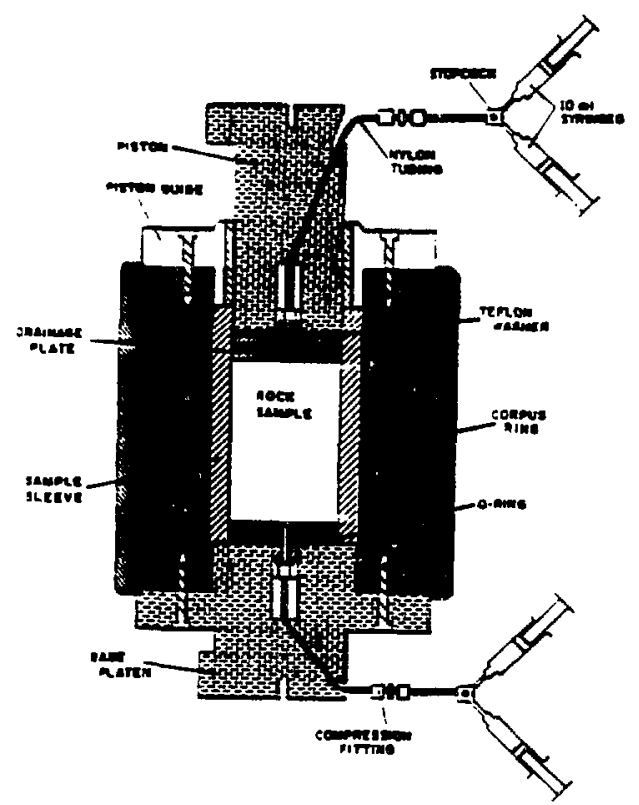

Figure 2. Scheotic diegren of one-dimmional coprestion cell uaed in this study

Axial stress ig applied to the core by a load frame that has a capacity of 915 megapacale. Pore water and gae are collected in syringea at the core ig compacted by the load. At the maximum axial stress, when water expulaion ceases and the core stopa compacting, additional pore water often can be extracted by injecting nitrogen gas into the pore epace. Pore water was filtered through a 0.45 micron filter and otored in polyethylene bottles prior to analyeie for dissolved ione. Pore gae was stored in glaga syringea prior to analyoes. Temperature measurements were made during several compreasion tegts using a chromela lumel thermocouple.

Water hav been extracted at preasures ranging from 34 to 828 megapacels from nonwelded cores having a degree of beturation as low as 16.2 porcent, and from wolded coree having a degree of aturetion ae low as 37.3 percent. The nonwelded cores yielded an average of $24 \mathrm{mill11}$ iters of water and 39 milliliters of gas. The wolded core yielded an average of $6 \mathrm{mill1-}$ litere of water and 15 mill111ters of gae.

\section{PORE-WATER AND PORE-GAS CHEAISTRY}

Analyaes of diseolved ionic epecies were performed on 449 water amples collected from 83 coro amples. Ga samples were collectad from ench of the 83 cores.

water anclyaee included determination of calcium, magnesium, odium, potastium, blcarbonate, chloride, ulfate, silice, nitrate, pH, and epecific conductance (SC). Water analyees were performad ueing ionepecific electrodes, ion chroutrography (IC), atomic abeorption (MA), and colorimetric methode. A 3-mililiter water sample 1e required for a cooplete analyais. Gav analyeev were performed by USGS permonnel ualng gas chromatography (GC) mothoda for carbon dioxide, wethane, and suifur hexafluoride determinations. A 3 milliliter ga: ample is required for a complete analyais.

Table I liste average chendcal compositions of water for each of the four representative tuff $B$. To obtain aufflcient water for chemical anelysed at various pregsure levele from low moisture content welded cores, an artificial pore water having an ionic composition ohown in table 1 was imbibed under a vacuum into 6 densely welded corea from the Grouse canyon Member of the belted Range Tuft to produce saturations of at least 98 percent.

Pore water extracted from nonwelded paintbruah Tuff core amplea is a calcium chloride type with a mean pH of 6.4 and $a$ mean SC of 890 microsiomenu per centimeter. Pore water extracted from a nonwelded geologic unit (Tunnel Bed 5 ) is a sodium bicarbonate type with a mean pH of 7.4 and a mean SC of 670 microsiemens per centimeter. Pore water extracted from a deneely welded geologic unit (Grouns canyon Member of the Belted Range Tuff) in G-Tunnel i: a sodium chloride type with mean pH of 6.5 and a mean SC of 610 microsiemens per centimeter. Pore water extracted from coree from a partially welded geologie unit (Apache Lasp Tuff) is a calcium oodium chloride type with a mean pH of 6.8 and a mean SC of 410 microsiemene per centimeter. carbon dioxide concentrations in the 
collected gas amples averaged 0.1 pereent and ranged from 0.01 to 1.3 percent of the gas composition.

Table 1. Average chemical compositions for four cepresentative tuff waters and an artificial pore water.

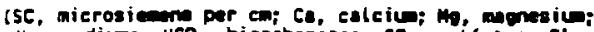

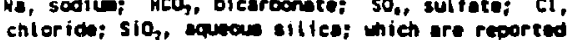
in milligraoser liter: HA, not aneivzed]

\begin{tabular}{|c|c|c|c|c|c|}
\hline & \multicolumn{5}{|c|}{ where souren } \\
\hline & MEI' & $\mathrm{Min} \mathrm{S}^{2}$ & place & PYAL & $A B C$ \\
\hline 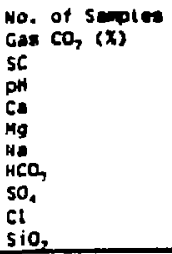 & $\begin{array}{l}03 \\
0.22 \\
890 \\
6.6 \\
93 \\
19 \\
42 \\
81 \\
120 \\
150 \\
76 \\
\end{array}$ & $\begin{array}{l}316 \\
0.07 \\
670 \\
7.4 \\
6.7 \\
0.9 \\
120 \\
150 \\
88 \\
23 \\
58\end{array}$ & $\begin{array}{l}21 \\
11 \\
610 \\
6.5 \\
22 \\
2.3 \\
100 \\
72 \\
92 \\
93 \\
95 \\
65\end{array}$ & $\begin{array}{l}9 \\
41 \\
610 \\
6.8 \\
66 \\
12 \\
43 \\
81 \\
48 \\
90 \\
62\end{array}$ & $\begin{array}{l}8 \\
\text { MA } \\
660 \\
4.0 \\
61 \\
1.3 \\
66 \\
30 \\
150 \\
85 \\
2.0\end{array}$ \\
\hline
\end{tabular}

1. nomelded, Pointbruan puft

2. nomielded, Tumbl ied 5

2 : nomelded, Tlumal Ged 5 " armon

4: perticlily walded, Apeche lece

5 - artificial pore uatar

The mineralogy of the four tuffo was analyzed and the reeulte axe shown in sable 2. The date in the table indicatere that the nonwelded roeka are componed primarily of elinoptliolite (a zeolite), with lesen amounts of clays and eanidine. The welded rock is composed primarily of sanidine, quartz, albite, and clayo. The partially welded rock from Arizona is composed primarily of albite, with leseer amounts of sanidine, quartz, and cristobalite. Cation-exchange capacities are about twlee as high in the samplea from nonwelded Tunnel Bed 5 at in the nonwelded paintbruth Tuff and cation-exchange capacitie: of gamples from the densely wolded tuff of the Grouse Canyon Member are minimal.

Table 2. Mineralogical compoeition of tuft samples.

Whiners! contene in pareent by volum; -.., not found; MA, not andized; minerslogical enelves by cryatel Researen hebaretory

\begin{tabular}{|c|c|c|c|c|}
\hline & \multicolumn{4}{|c|}{ Tute } \\
\hline & MUPT & 4urs' & OUEC: & PUAL \\
\hline $\begin{array}{l}\text { Cation exchenge cepactey } \\
\text { Sanidine } \\
\text { Albite } \\
\text { Duartz } \\
\text { Christobelite } \\
\text { Chalcedony } \\
\text { Clinopllolite } \\
\text { Ferric lllite } \\
\text { lllite/Montmorillonite } \\
\text { Biotise }\end{array}$ & $\begin{array}{l}91 \\
3.8 \\
1.1 \\
1.7 \\
5.2 \\
4.5 \\
66 \\
4.3 \\
10 \\
1.5\end{array}$ & $\begin{array}{l}175 \\
12 \\
0.4 \\
1.4 \\
7.8 \\
67 \\
11 \\
\cdots \\
\cdots\end{array}$ & $\begin{array}{l}4.3 \\
48 \\
16 \\
27 \\
\cdots \\
0.8 \\
9.8 \\
0.3 \\
\cdots\end{array}$ & $\begin{array}{l}M A \\
16 \\
65 \\
15 \\
15 \\
6.0 \\
\cdots \\
\cdots \\
6.0\end{array}$ \\
\hline
\end{tabular}

1. anv use of firm numes is for detcriptive purposes ontr and does not imply endorsewent by the U.S. Government

2. nomulded, Paintbruth Iuff

3. nomuld ded. Tunnal bed 5

4 - densely welded, Grouse camyon

5 - oartially welded, Apacre leep
The wacer analyoes were evaluated by using the computer program whTEQF (Plummer and ochers. 1976), a FORTRAN program that models thermodynamic speciation of Inorganic ion: and complex species in golution. The use of tha aaturation-index data from WATEQE, a knowledge of the phases known to oceur in a syetem, and geochemical intuition can determine whether a epeciflc mineral phaee would disaolve or precipltate and whether ion exchange or other resctione could be oceurring. Average eaturation indices for the mineralo most prevalent in the four tuffe are shown in table 3. saturation indices greater than zero indicate super saturation.

Table 3. Average saturation indices determined by the computer program WATEQF

$$
\text { 6-- indicetes eimerel not incortent to }
$$
specific tuff troel

\begin{tabular}{|c|c|c|c|c|}
\hline & \multicolumn{4}{|c|}{ Tutf } \\
\hline & MLP' & MUTS ${ }^{2}$ & ouct & PHAL" \\
\hline Albite & -. & 1.4 & -1.1 & 0.0 \\
\hline Chalcedomy & 0.6 & 0.6 & $\cdots$ & 0.4 \\
\hline Chriatobstite" & 0.7 & 0.7 & 0.3 & 0.5 \\
\hline Illite & 5.5 & 5.0 & 2.9 & -. \\
\hline Montmortllonite & 0.9 & $\cdots$ & $\cdots$ & - \\
\hline : luarte & 1.1 & 1.1 & 0.7 & 0.9 \\
\hline 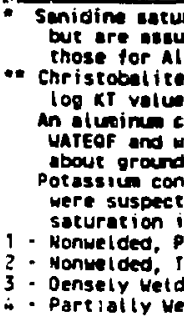 & 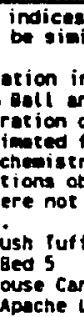 & $\begin{array}{l}\text { not } \\
\text { to or } \\
\text { ses wer } \\
\text { lordstr } \\
11 \text { mif } \\
\text { putil } \\
\text { ned ir } \\
\text { d in t }\end{array}$ & 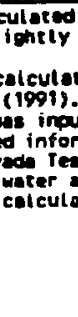 & $\begin{array}{l}\text { nesteef } \\
\text { wes then } \\
\text { wing } \\
\text { into } \\
\text { ation } \\
\text { site. } \\
\text { iveses } \\
\text { ion of }\end{array}$ \\
\hline
\end{tabular}

\section{INTERPRETATION}

Poseible caues of pore-water chemistry changer that occur an a function of increasing preanure during compression are discuseed bolow.

Dilution by compreseion of claye and zeoliter and releaes of lon-deflcient. previouely-bound water (van olphen, 1963) would revult in progreasively decreaving Ion concentratione. Figure 3 denonetrates ion concentratione for a nonwelded tuff sample are coneigtent with this mechaniem. The volume of ion-deficient bound water required to produce the observed ion concentration decreases were calculated to represent about 5 to 33 percent of the available bound water in the zeolitea.

The interaction of pore-water with carbon dioxide gas contalned in unfliled pore space would forto a weak carbonic acid solution that could cause pH or alkalinity changes and dianolve minerale. The total moles of carbon in the gas phase were calculated using mean carbon dioxide con- 
centration and mean milliliterg of gan collected. The total moles of carbon in the aqueous phave were calculated using mean bicarbonate concentration and the mean total milliliters of water avallable. Calculated amounts $\left(1.2 \times 10^{\circ}\right.$ moles in gae and $1.1 \times 10^{-6}$ noles in water) indicate that tha gae phaee could be an important component of the chmietry of these watere. Difeolution of minerale due to carbon dioxide diseolving into golution or due to the creation of fresh surfacen by the compreveion procese could caues increaee in calcium, magnesium, sodium. potabeiun, and eilice. No elgnifleant increases in any of theae conetituente are sean as a result of compreseion (Flgure 3 ). Thus, if ditwolution is occurring, it is being counteracted by another mechanisu.

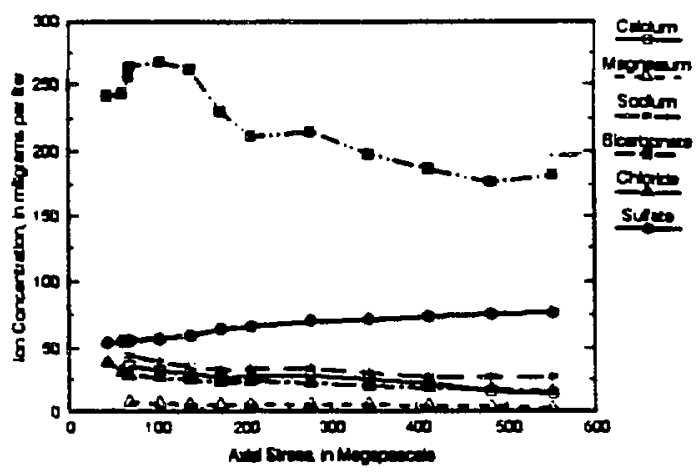

Fig. 3. Chnnges in major lon concentrations in nomwelded tuff with increeding applied premeure

Precipitation of minarals dus to changes in saturation stated of the pore water because of other reactione occurring during compresaion would decrease ion concentrations. The securation indices indicate supersaturation with reepect to all ralevant rock minerale. However, the kinetics for the formation of thee minerals would probably preclude their precipitation during compreseion.

Membrane filtration of iona may occur ae they flow ehrough a semipermeable membrane (Bredohoeft and othere, 1963). The compresed clay and zeolite minerale may act a) a cemipermeable membrane caueing a decrease in ion concentration and a change in the relative proportione of ione. Preferential adsorption of sodium wae ahown by Hanghaw (1964) and Hanshaw and Coplen (1973). Some galectivity for aniona has been ghown but is lese defined. Decreases in cations are obverved in water from the nonwelded Tunnel Bed 5 tuff and nonwelded Paintbruah Tuff core bamples, with sodium having the greateet decrease (Figure 3 ).

Ion exchange reaction, involving both cations and anions in the pore water from the rock meerix and from the clay and zeolitee, would be reflected in total ion concentrations as well as in the relat proportions of ions. Changes in the rel tive ion proportions would be indicated increases in sodiun relative to calciu and bicarbonate and oulfate relative chloride. In the artificially saturar deneely wolded Grouse canyon tuff. change in chemiatry between the artifici pore water and the final compreaed wat indlcates an increase in sodium and decrease in calcium (Elgure 4 ).

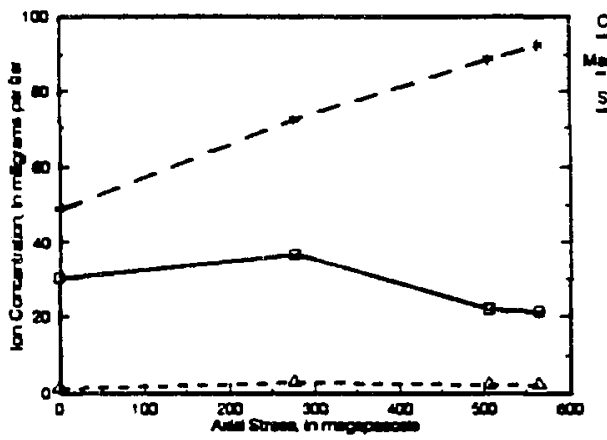

Flo 4 Changes in major cotion conoentinutione in artiflel cturntad Crous Cenyon Tutfe whth inoreneing appled pr

Evaporation of pore water due to 1 seorage perioda would cause drying to oce syetematically from the outside of the c inward toward the center, leaving boh the discolved salts. The initial wat cemoved from the core would diasolve th salts, causing increased concentrati that would submequently decrease al ad tional water samples were collected. relative proportiona of ions would rem constant. Although the data are consiat with this mechanism, figure 5 indica very little correlation batween the len of time sealed and decreases in SC w compression. Thus, dilution by adsor water seeme more likely than slow accumu tion of saltb due to evaporation.

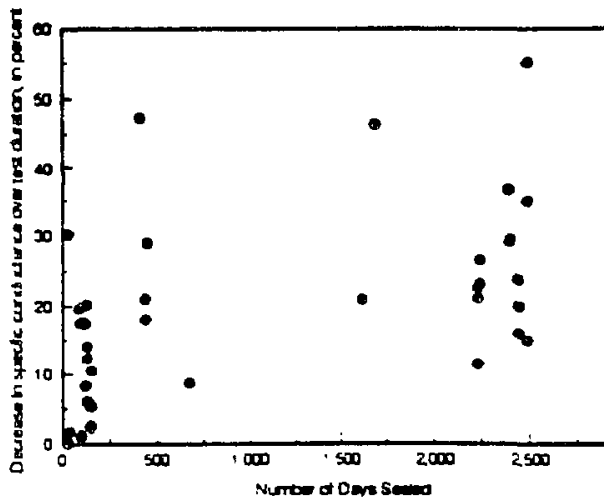

Fig. 5. Relstion bureen numbey of daye mated and the In spectic conductance of extracted water from all t 
As a reeult of the compreseion procese, Temperature and preesure changes could result in ion conceneration rhanges. Temperatures 2neide tha compreseion cell and of extracted water changed little during compreasion. Although the rock core is being subjected to 830 megepascale during compreseion, the amount of preveure acting on the gae and water in the rock probably is much lene because the extraction routes are open to the air. Therefore. the wior effoct of the preemure if probably to caues gee to be dienolved into the pore wator. Thus, the effects of preseure are probably lialted to the carbonete oyetain, as deceribed proviourly.

Hydraulic drag effecte caued by the moverent of diseolved lons paeing through the electric double layere near clay and zeolite surface would retard lazger, divalent lone relative to bmeller, univalent ions (Fharaka and Berry, 1973). Relative concentration effects cauend by the rixing of clay- and zeollte-adeorbed wetere and pore water can result in an lon concentration increase during compreveion of the core (Appelo, 1977). Nithough these mechaniem are poevible, and are at leat pertly upported by the data, their impact is even a minor.

\section{CONCLUSIONS}

The mechanisms responaible for changes in ion concentrations due to compreasion that appear moet probable for the tuffe considered include: dilution by zeolite-adeorbed water, diseolution of carbon dioxide gae into the pore water during compreselon, and membrane-filtration and ion-exchange ef tecte caui, id by the presence of the claye and zeolitee. Planned further investigatione of the mechaniens includes 1) analyeia of pore water from difteront preseure levele for oxygen $18 / 16$ and deuterium/hydrogen isotope rarios to aid in determining if the dilution of pore water by 2001 ite-adeorbed water and the membrenefiltration eftecte are occurring; 2 ) analyees of aluminum, 1ron, and other trace elements to better determine the effecte of poseible mineral dissolution: 3) analyees of carbon dioxide concentratione in water and carbon-is ages of both the pore water and gae to better determine the carbonate system effecta: 4) the uae of varioue geochemical modela, including poseibly PHREEQE (Parkhurat and others, 1980) and NETPATH (Plummer and othera, 1991); and 5) rock analyois to gain further information concerning the effecta of compreasion on mineral surface araa.

\section{REFERENCES}

Appelo, C.A.J., 1977, Chemistry of water expelled from compaceing clay layera: a model baeed on Donnan equilibriur: Chamical Geology, v. 19, p. 91-98.

Ball, J.N., and Nordetrom, D.K., 1991. Uner' manual for WaTEQ4F, with rovised thermodynume date base and teet caese for calculating apeciation of major, trace, and redox elements in netural water: U.S. Geological Survey open File Repore 91-183, $189 \mathrm{p}$.

Bredehoeft. J.D., Blyth, C.R., White, W.A. and Mexey, G.B., 1963, Poteible mechantere for concentration of brines in -libourface formations: Bulletin of the American Aeaciation of Petroleur Geologiste, V. 47, p. 257- 269.

Hanehaw, B.8., 1964, Cation-exchange constante for clay from alectrocheraical measurwante: National Conference on Claye and clay Minerala, 12th, Atlanta. 1963. Prosendinge, P. 397-421.

Harehaw, B.B.. and Coplen, T.B., 1973. Ultraflitration by a compacted clay membrene-II. sodiue ion exclueton at variou ionic etrengthes Goochimica et Coumochinica Acta, v. 12, P.225-226.

Khazake, Y.K., and Berry, F.A.F.. 1973. simultaneoue flow of weter and colutea through geologic menbranee--I. Experioental Investigation: Geochimica et Conmochlotca Acta, $v$. 37, p. 2577-2603.

Mower, T.E., Migrine, J.D., and Yang, I.C., 1990. Trlaxial- and uniaxial-coupreseson tenting methods developed for extraction of pore water from uneturated tuff. Yucea Hountain, Nevada: in Proceedinge of Focus '89: Nuclear wate ieolation in the unaturated zone: LaGrange Park. IL. American Nuclear society, p. 426-433.

Parkhurat, D.I.., Thorstenson, D.C., and Plummer, L.N., 1980, PHREEQE-A computer program for geochemical calculatione: U.S. Geological Survey Hater-Romource Inveatigatione Report 80-96, $146 \mathrm{p}$.

Plumner, L.N., Jones, B.F., Truendale. A.H., 1976, wateQE - A fortran IV varsion of HATEQ, a computer program for calculating chemical equilibrium of natural watera: U.S. Goological Survey Water Resource inventigationa Report 7613. $63 \mathrm{p}$.

Plummer, L.N., Preetemon, E.C., and Parkhuret, D.L., 1991, An interactive code (NETPATH) for modeling net geochemical reactiong along a flow path: U.S. Geological survey water Resources Investigations Report 91-4078, $227 \mathrm{p}$.

van Olphen, H. 1963. Compaction of elay sedimente in the range of molecular particle dietancea: in Claye and Clay Minerala, Proceedinga llth National Conference, ottawa, Ontario, Canada, 1962. H.F. Bradley, ed. Pergamon Preas. New York, p. 178-187. 